\title{
Improving Parents' Attention to The Interest of High School Students Continuing Study in Higher Education through a Parenting Program
}

\author{
Ninin Irmawati ${ }^{1, *}$ Najlatun Naqiyah ${ }^{1,}$ Hadi Warsito ${ }^{1}$ \\ ${ }^{1}$ Pascasarjana Bimbingan dan Konseling, Universitas Negeri Surabaya. \\ *Corresponding author.E-mail: $\underline{\text { nininirma.20014@mhs.unesa.ac.id }}$

\begin{abstract}
ABSTRAK
Continuing to college is the dream of high school graduates living in urban areas. With good grades in semesters 1-5, they can pass SNMPTN with a study program that suits their interests, especially if they have KIP or PIP scholarship cards. With KIP they do not need to spend money, tuition fees are free, and they even get pocket money. Those who do not pass the SNMPTN can also study for free with KIP at private universities. The reality is not the case because of $80 \%$ of KIP recipient students, only $20 \%$ are willing to continue. The main reason given is because of the parents' economy, even though they have been socialized about the existence of KIP, their decision has not changed, therefore a parenting program is held. The purpose of this study was to determ ine the improving effect of the Parenting Program to increase parental attention to the interest of class XII students to continue their studies at SMA Negeri 3 Bondowoso for the academic year 2020-2021. This research uses the experimentalmethod. The study results stated that there was an increase in parentalattention and student interest in continuing to college after the parenting program was implemented.
\end{abstract}

Keywords: Parenting program, Parent's attention, Interest, PIP.

\section{INTRODUCTION}

The NationalEducation Goals are written in Law no. 20 of 2003 Article 1 paragraph 2 which is based on Pancasila and the 1945 Constitution of the Republic of Indonesia. The meaning of education is also stated in Law no. 20 of 2003 article 1 paragraph 1, which states, "Education is a conscious and planned effort to create a learning atmosphere and learning process so that students actively develop their potential to have religious, spiritual strength, self-control, personality, intelligence, noble character, and skills that needed by himself, society, nation, and state.

According to the law above, it can be explained that education must be sought, planned, and developed by each individual, so that he/she acquires the abilities and skills in accordance with his/her potential. Education will make them strong and independent, become adults, and gain broad insight as a provision to live in society. By its function, education can shape humans into dignified individuals, become human beings who believe, are intelligent, have a noble character, and are responsible for their nation, state and religion.
Continuing to college is a must for every high school or vocational high school gra duate who has the ability in terms of material and knowledge. By continuing education, the knowledge of these graduates will increase. Every graduate can have a reason to continue to higher education, both public universities and private universities. These reasons include: wanting to become an expert or specialist in the field in question, for example, an expert/specia list in economics, medicine, biology, physics, chemistry, and others. The following reason is that continuing to college will open the door to a career that is by choice of major, besides that it will also open up job opportunities and be taken into consideration because there may be many companies thatopen vacancies for college graduates.

At the beginning of every yearor the beginning of an even semester, every State University in Indonesia organizes the recruitment of new student candidates who are members of the SNMPTN or stand for the National Selection of State Universities. As usual, prior to implementing the SNMPTN, the Guidance and Counseling teacher recorded data on students who wished to continue to higher education even though it had been done in the previous year. This student data collection activity is carried out 
every year because sometimes students change their minds from wanting to continue to discontinue or otherwise seeing the condition of theirfamily/parents.

What is meant by the parents' condition is the family's condition, which is influenced by several backgrounds of both parents. The background conditions such as the educational background of both parents, the association of parents, either with neighbors or with relatives who are close to the family, economic or financial conditions of the family. In addition to the two conditions above, the location of residence also affects the reason why high school graduates do not continue, for example students who come from the village, usually already have a fiancé and are ready to be married after finishing school, another example is the children in female boarding schools as well, after school in his hut they will also be married off.

The condition of these parents is very closely related to the pattern of child-rearing. The factors that influence parenting are parental education, environment, and culture. According to Maccoby \& Mcloby [1], several factors influence parenting patterns for children, namely: (1) socioeconomic factors, (2) education, (3) religious values adopted by parents, (4 ) personality, and (5) the number of ownership. The economy of parents greatly affects the continuation of students' studies because with sufficient funds, the students concerned can continue to college. With sufficient parental education, it will affect the perception of parents about education, at least the appropriate parental education will support their children to take education at least the same as their parents. Deep religious knowledge can be a very strong foundation on the human personality because seeking knowledge is a worship that is carried out as a form of love for religion and its creator.

[2] describes that the success of families in educating their children is very dependent on the model and type of parenting applied by the parents. Knowledge and understanding of parents about parenting are very supportive of their children's success, especially in realizing the ideals of children.

The results of observations made by researchers before the study on PIP recipient students who did not continue showed that parents were less supportive of their children's education. The rea sons stu dents do not continue because they want to work to ease the burden on their parents, parents leave the decision after graduating from high school to their children, parents are worried that education will stop midway due to lack of funds, and most students say they are lazy or tired of thinking because school has too many assignments and worried about not being able to understand the material taught in college.

According to [3] eight factors cause children not to continue their education to tertiary institutions: the willingness of children to continue their education to the causes of not continuing their education to college, education costs, community environment, family income, number of dependents, a wareness of the importance of education, family environment, friendly environment.

Table 1. Graduates of SMA Negeri 3 Bondowoso who obtained a Continuing PIP and did not continue to Higher Education

\begin{tabular}{|c|c|c|c|c|c|c|c|}
\hline \multirow{2}{*}{$\begin{array}{c}\text { School } \\
\text { Year }\end{array}$} & \multicolumn{3}{|c|}{ College } & \multicolumn{3}{|c|}{ Melanjutkan } & \multicolumn{2}{c|}{$\begin{array}{c}\text { Army/Police } \\
\text { Amount } \\
\text { of } \\
\text { Student }\end{array}$} \\
\cline { 2 - 8 } & Amount & Percentage & Amount & Percentage & Amount & Percentage & 45 \\
\hline $2020 /$ & 10 & $22,22 \%$ & 35 & $77,77 \%$ & 1 & $2,22 \%$ & 64 \\
\hline $2021 /$ & 30 & $47 \%$ & 26 & $41 \%$ & 14 & $12 \%$ & \\
\hline
\end{tabular}


Based on the data in table 1.1, it can be seen that the number of students who continue is less than students who do not continue, even though they already have a PIP scholarship, it is not a motivation for them to continue. There are only two academic year periods, namely the 2020-2021 academic year period, because the PIP Law was only enacted in 2020 so that before 2020 no students received PIP scholarships. At the same time the data for the 2021-2022 school year, is the latest data taken by researchers in October 2021 and is the data to be studied.

The presence of SNMPTN is good news for students who want to continue to state universities because it can increase their enthusiasm. They feel honored as a student, satisfied with their achievements for five semesters, and feel that their efforts are not in vain if they are accepted at one of the state universities with only five semesters of grades. The students also feel they can be proud of their parents, especially if their names are displayed on the school banner and seen by all their juniors and their parents who come to school. Not only the reasons above, the joy of welcoming SNMPTN is because students do not need to compete through tests but enough to use their report cards from class $\mathrm{X}$ to class XII.

In fact, many students including students who can apply for SNMPTN refuse to register or in other words do not want to continue, even to private universities (PTS). From the results of the researcher's observations, there were several reasons that caused the PIP recipient students not to continue, namely economically incapable, not ready for college, lazy, wanting to work alone, forbidden by their parents, wanting to help their parents, many undergra duate graduates who unemployed, and so on. After calling the parents, the most common reason is that they are economically incapable, even though they have PIP, and have received socialization, but the answer remains the same, not continuing their education to college.

Based on the reasons above that motivated the researcher to take the research title "Improving Parents' Attention to the Interest of Higher School Students Continuing Study in Higher Education Through Parenting Program".

\section{METHOD}

This research includes experimental research. Experimental research is research by conducting an objective, systematic, and controlled study to predict or control phenomena [4]. The purpose of this study was to investigate the causal relationship of increased parentalattention and student interest in continuing to college. After implementing the parenting program.
The population of this study is of two kinds, namely the class XII students of SMA Negeri 3 Bondowoso for the academic year 2021-2022, totaling 160 people and their parents. The research sample was taken from 64 PIP scholarship recipients and their parents, then the students were divided into two groups, the first group was 30 students who wanted to continue their studies and 34 students who did not want to continue their studies. All student samples will be taken so that the research results are better and more accurate and can be used as a reference for programs by schools to motivate students' interest in continuing to college. Samples of parents were taken related to parenting program variables and parental attention.

The sampling technique uses a purposive sampling technique because it is carried out based on a specific purpose. The purpose of the sample is to take the subject, not based on strata, random, or regional but based on a certain purpose [5]. According to [4], "Purposive Sampling Technique is the determination of the respondent's method to be sampled based on certain criteria."

The time of the research is planned to be carried out at the end of October and November 2021 and takes place at SMAN 3 Bondowoso.

Data collection methods used by researchers in this study are as follows: Indirect communication is a data collection technique carried out with an intermediary tool in the form of a questionnaire or questionnaire addressed to parents and children who receive PIP. The questionnaire in this study used closed and open questions. There are two classes, students who continue and do not continue, one class that continues as a comparison class.

Data collection tools in this study are: questionnaires/questionnaires. According to [5] "Questionnaires or questionnaires are a number of written questions that are used to obtain information from respondents in terms of reports about themselves, or things they know".

In carrying out data analysis, the author uses a T-test (product moment) with regression analysis techniques, namely to test the truth or falsity of the null hypothesis which states that the average sample taken at random from the population has no significant difference. The hypotheses in this study are:

- Ho : There is no increase in parentalattention to students' interest in continuing their studies to college through parenting programs,

- Ha: There is an increase in parentalattention to the interest of students to continue their studies in higher education through parenting programs.

With the following hypothesis testing criteria:

- If $\mathrm{t}$ count $<\mathrm{t}$ table then $\mathrm{H} 0$ is accepted and $\mathrm{H} 1$ is rejected 
- If $\mathrm{t}$ count $>\mathrm{t}$ table then $\mathrm{H} 0$ is rejected and $\mathrm{H} 1$ is accepted.

\section{RESULTS DAN DISCUSSION}

The results of the program providing material in the parenting program are expected to influence the attention of parents, so as to encoura ge students who receive PIP to continue to college as much as $80 \%$. After a nalyzing the data, it is continued by testing the accepted hypothesis. Testing is done by determining whether $\mathrm{H}$ zero is accepted or $\mathrm{H}$ zero is rejected and $\mathrm{H}$ is accepted. The criteria are:

- $\quad H 0$ is accepted if $t_{\text {count }}<t$ table

- $\quad H 0$ is rejected if $t_{\text {count }}>t_{\text {table }}$

\section{CONCLUSION}

The Indonesian government has provided opportunities for the Indonesian people to learn and continue their education, both primary, secondary and further education with facilities in the form of the Smart Indonesia Program (PIP). This is intended so that education is evenly distributed throughout the Indonesian people so that there is no difference between the upper, middle and lower classes.

This parenting program is carried out with several steps such as PIP socialization by alumni of PIP recipient schools, observation, sharing about child care and PIP recipients. Other material provided in the socialization is the understanding of parents about education, further studies, higher education, the role of parents and the understanding of quality children.

This program is very important to be implemented in every school, not only in high school but can be extended to other schools, so that people understand the importance of education and fully motivate their children to continue their education. Especially for parents whose children get PIP scholarships.
Based on the results of the data calculation, it is expected that there will be an increase in parental attention and interest in continuing their studies to college through the parenting program. This research is recommendative, meaning that it can be used as a reference for further research.

\section{AUTHORS' CONTRIBUTIONS}

All a uthors conceived and designed this study. All authors contributed to the process of revising the manuscript, and at the end all authors have approved the finalversion of this manuscript.

\section{REFERENCES}

1. Madyawati L. Strategi pengembangan bahasa pada anak. Kencana; 2016.

2. Agus W. Pendidikan Karakter Anak Usia Dini: Pustaka Pelajar. Yogyakarta; 2012.

3. Pujianto D, Syahrudin H. FAKTOR â€"FAKTOR PENYEBAB ANAK TIDAK MELANJUTKAN PENDIDIKAN KE PERGURUAN TINGGI. J Pendidik dan Pembelajaran Khatulistiwa. 2015;4.

4. Siregar S. Statistik parametrik untuk penelitian kuantitatif. Bumi aksara; 2014.

5. Arikunto S. Prosedur Penelitian Suatu Pendekatan Praktek. Jakarta: Asdi Mahasatya.. 2006. Prosedur Penelitian. Jakarta: Rineka Cipta.. 2010. Prosedur Penelit. Suatu Pendekatan Prakt. 1998. 